\title{
Capitalism, Income Inequality, and Education
}

\author{
Donald K. Sharpes \\ Arizona State University, Tempe, USA; \\ Cambridge University, Cambridge, UK
}

\begin{abstract}
There is a strong relationship between capitalism as an economic model, income inequality, and education. Statistical data collected by American and international organizations reveal a widening gap between incomes disproportionate to the public good. A dwindling of income leads to a diminishing of tax revenues, and hence, on public expenditures on education that in turn degrades future educational quality. Government and private industry need to seek a more equitable balance of resources for the commonweal.
\end{abstract}

Keywords: capitalism, income inequality, education

\section{Introduction}

America's global, technology-driven economy has lifted the financial boats of the more highly educated, while the majority of the population has sunk into menial, lower-paying jobs, depleted what minimal government and personal savings existed, and dashed hopes for an improved future. In this paper, the author would like to demonstrate the relationship between capitalism and the growing levels of income inequality that in part has caused a significant decline in educational standards and quality.

\section{Capitalism and Wealth Inequality}

Money! There is nothing in the world so demoralizing as money.

Down go your cities, homes gone, men gone, honest hearts corrupted, crookedness of all kinds, and all for money. (Creon in Sophocles' Antigone)

The three dominant political and economic issues of contemporary Western societies that are inter-related and that the author addresses in this paper are:

(a) The rapid growth of economic inequality;

(b) The corresponding stratification of society;

(c) The role of government in correcting or modifying fiscal imbalances.

Government policies, and the lack of them, have directly caused growth in economic inequalities, a disproportionate social stratification, and a decline in education spending. The American conservative political right wants to curtail spending and taxes to keep the economic machine running. The more liberal left seeks to increase government spending to stimulate slow growth, and to help benefit those on the lower economic strata. But both sides of the political spectrum are not considering the rising tide of social instability that can generate a populist backlash creating social disorder.

It was the creation of the modern welfare state in America, chiefly during the Franklin Roosevelt

Donald K. Sharpes, Ph.D., professor, Emeritus College, Arizona State University; senior visiting fellow, Cambridge University. 
Administration, that established educational, work, and social programs, that finally allowed democracy and capitalism to co-exist in a relative harmonious state. It is reasonably argued that legislated policy initiatives - like unemployment insurance, food stamps, and Medicaid - to the economically disadvantaged create injustice among others who believe that the so-called government handouts are not earned through merit.

For example, according to the U.S. Census Bureau (2013), 10\% of all households were on food stamps in 2004. By 2013 , that percentage had doubled to $20 \%$ of all households, primarily because of wage inequalities. The cost of the government program increased $42 \%$ from 2009 to 2013 when the recession hit with full force. This is why tax-cutting conservatives sought to cut the program's beneficiaries as a curtailment of big government, a slogan used to slash all social budgets, but not the military and defense. One quarter of all children benefit from food stamps, an awesome burden for the families. Slicing this program is a blotch on the American badge of compassion, of taking care of the unfortunate and its children.

On the other hand, maintaining a dynamic economy though capitalism is only one leg of a modern democracy. Providing benefits as a percentage of the economy's total national strength is the other leg of the economy, the price a nation has to pay for aiding the lives of citizens who fear increased disenfranchisement and insecurity. Conservative congresses have systematically adhered to ideological priorities like these factors: tax cuts for the wealthy that presumably help the economy and trickle down to workers, that austerity floats all boats, and that the markets regulate themselves without government interference. Schemes based on these premises have been discredited. The other discredited notion is that somehow presidents unduly influence economic outcomes.

Thomas Piketty's 2014 book, Capitalism in the Twenty-First Century, reveals economic data over the last 300 years and shows the negative influence of high rates of income inequality (Piketty, 2014). Nobel Prize winner in economics, Joseph Stiglitz, made a similar case in his book The Price of Inequality (Stiglitz, 2013, cf. also Muller, 2013). Fragility in economic growth, widening income disparities that create an aristocracy of wealth, and reluctant political will to change policies has resulted in apathy about slowing income inequality.

America's economy had crystalized at the beginning of the 20th century based on capitalism's of enormous financial appetites. Our economy, then as now, maintains the same elements - the ownership of production, the exploitation of labor and of natural resources, whether in oil, coal, timber, or food products, and large-scale distribution that created the first mass consumer culture.

That legacy is built on the slogan of laissez-faire capital economics first proposed by the robber barons in the 19th century as a way of protecting their money. It is not based on the constitutional pledge "to promote the general welfare," which presumes that the public's good is preferable to private gain.

It is an illusion to think that income inequality will become more equitable, or that the laws of the marketplace, besides the profit incentive, will somehow decrease wealth inequalities and result in financial harmonies between the rich and ordinary workers. Wealth has always been in safes of the rich. It is just that in this part of the 21 st century, it is more concentrated than ever in the top $10 \%$ of the wealthy resulting in a greater number of individuals and families in poverty. The so-called middle class has less purchasing power. At a time when consumer spending drives the economy, ordinary consumers have diminishing funds to purchase anything.

An extremely conservative body of the U.S. Congress has prevailed in preventing any even modest increase in taxes for the wealthy, and hampered efforts to regulate the financial industry that appears to be strangling ordinary laborers. Worse, they declare publicly that the unemployed are somehow lazy and unwilling 
to work, yet never cite any research study or evidence to bolster that claim. Disparaging the poor and unemployed is a convenient way of getting like-minded conservatives to vote against government programs that aid the economically less fortunate whose condition is by and large not their fault but that of the depressed economy.

About $60 \%$ of the newly created jobs go to hourly wage-earners receiving, if they are fortunate, about $\$ 15$ an hour, such as those with good jobs in car manufacturing plants. Raises in the minimum wage will hardly cause a ripple in the economy, but will give a breath of relief to those in the lower income earning class. About $25 \%$ of Americans considered themselves lower or lower-middle class in 2008. In 2014, that percentage rose steeply to $40 \%$.

According to the U.S. Bureau of Labor Statistics in a report issued in April 2014, the occupations with the largest employment were retail salespersons and cashiers. The 10 largest existing corporations provided $21 \%$ of new employment. The average worker earned $\$ 22.33$ an hour, or $\$ 46,440$ annually. These are the kinds of job immigrant laborers and typically women can provide, and usually that those unemployed from other jobs do not seek.

Since 1980 , wages have increased about $8 \%$ while productivity has risen $63 \%$, noted by Professor Thomas Kochan of Massachusetts Institute of Technology (MIT). The national goal should be to bring these two figures more into balance, and to give to workers the majority share of the nation's wealth and reduce the inequality.

There has always been a gap between the wealthy and the poor, but wages for the working class were flat for the seven years between 2008 and 2014. Moreover, salaries for white-collar workers have also been stagnant, stuck at $\$ 455$ a week (in 2014), equaling $\$ 23,660$ annually, below the poverty line for a family of four. Corporations slashed worker pay and benefits, and eliminated competition through price wars and mergers. It also allowed Wall Street firms to experiment excessively with new kinds of securities that bordered on gambling. It is discovered what money was not in 2008-it was not collateralized debt obligations, securitized mortgage-backed assets, or derivatives.

Let us outline the sad figures from 2015, so the financial status of average Americans is clear:

(a) Average credit card debt among indebted households: $\$ 15,263$;

(b) Average credit card interest rate: $14.95 \%$;

(c) Average mortgage debt: $\$ 147,591$;

(d) Average outstanding student loan balance: $\$ 31,646$;

(e) Average auto loan debt: $\$ 30,738$;

(f) Only $59 \%$ of Americans have at least $\$ 500$ in a savings account.

With the initial rise of capitalism, the sources of income were jobs generated by manufacturing. The possibility of the loss of a job created its own fear and insecurity resulting in the creation of protective agencies like unions, and the passage of laws protecting the worker. The erosion of a stable economy, the loss of manufacturing jobs, combined with decreased governmental support from conservatives for social services, inevitably led to less tax revenue and steep declines in most publicly funded activities like schooling. In addition, because of the attraction of credit through the liberal use of credit cards and other inducements, Americans indebted themselves and resisted any raise in taxes, even to support schooling or other public investments.

America preached a capitalistic religion to the rest of the world, and the globalized world got the message that using increasing amounts of debt to increase assets was necessary. But the result for everyone was a 
delusion of gigantic proportions. One direct consequence was a significant decrease in public investments. This downturn in economic strength - a housing bubble beginning in 2008 fueled by unrealistic claims of permanent rising housing values and repackaged financial loans, and a weakly regulated financial industry—resulted in a widening chasm in income equality.

\section{Results of Income Inequality}

No society can surely be flourishing and happy, of which the far greater part of the members are poor and miserable. (Adam Smith, The Wealth of Nations, Book I, Chapter 8, p. 96, para. 36)

Income inequality has become the most controversial topic about capitalism's social advantages and disadvantages, and it is a global phenomenon. The richest 100 people in the world have more money than half the world's population, or the poorest 3.7 billion people.

Conservative government policies and laws have lowered corporate income taxes and personal taxes for corporations and the wealthy. By default, therefore, income inequality has burdened the poor and middle classes with the majority of taxes necessary to sustain a host of public expenditures, including education. Contributing to this is the attempt by conservative politicians to privatize public schools, like the establishment of charter schools and the use of vouchers.

Nothing speaks more loudly about income inequality in the U.S. than the comparison between minimum wage laborers who work full time and bonuses paid to Wall Street bankers. In 2014, the total bonus pool paid out to bankers was roughly double that paid to all minimum wage earners. In other words, 167,000 bankers were given $\$ 28.5$ billion, or an average bonus of $\$ 172,860$.

In the 1960s, chief executives were paid roughly 20 times as much as their employees, compared with more than 300 times in 2013, according to the Economic Policy Institute in 2014. Service workers tend to work around 40 hours a week on average. If they all earn $\$ 7.25$ per hour and work 50 weeks per year, the total earnings of this group come to nearly $\$ 15$ billion, just less than half the banker bonuses.

A remarkable $95 \%$ of income growth has gone to the super-wealthy. The bottom $90 \%$ of all American wage-earners - those making about $\$ 31,000$ a year or less- have seen a decline of $24 \%$ in their income (Gilson, 2014). ${ }^{1}$

Touting major corporations and businesses as job creators is bogus, and the data belie the specious argument. Corporations have in fact shipped jobs overseas, hidden taxable earnings overseas, demanded lower tax rates on what they do earn, and in an arrogant display of excess given huge generous bonuses to executives. Except through an equitable share in taxation, business is not required to provide for the general welfare.

The premise of most radical conservative thinking is that government should have no business in business. Let us assume for the sake of argument that that should be the rule, because ever since the Reagan Administration's attempts at unregulated government, especially over the financial sector, that has been the operative policy. What have been the results? The answer is the creation of an economic aristocracy of plutocrats and corporate allies.

\footnotetext{
${ }^{1}$ For an analysis of how the rich got richer because of government policy favoring business, see Barlett and Steele (2012). Moreover, wealthy constituents have a larger voice among representatives: "All in all, our research strongly suggests that American democracy is, indeed, unequal. Members of the House of Representatives, especially Republicans, are much more responsive to their wealthier constituents than they are to their low-wealth constituents" (Rhodes \& Schaffner, 2013).
} 
Here are five of the major consequences of that policy:

1. Jobs have drifted overseas, not just because of technological advances, but because corporations sought lower labor costs, no contracts with unions, and no benefits to workers. Between 1999 and 2008, prior to the financial collapse, more than 2,000,000 jobs went overseas.

2. The tax code has been skewed primarily for the rich. By 2012, there were 116,000,000 tax filers, of whom 58,000,000, exactly half, were below middle class incomes. In 1955, the 400 richest households paid $51.2 \%$ of income in taxes. A half century later in 2007 , the same income group paid only $16.6 \%$ in federal taxes. The top tax rate in 1981 was $50 \%$. Now, it is $35 \%$. In 1980 , the maximum tax rate on capital gains was $28 \%$. In 2012 , it was $15 \%$.

3. Special interest lobbying groups continue to write legislation that favors their products or operations, and not current benefits to workers, including the erosion of pension plans. Recall also that President George W. Bush sought to privatize social security. In the meantime, executive compensation and bonuses are ballooning.

4. Radical conservative groups, including about half of all members of Congress, attempt to reduce or eliminate programs that benefit workers, children, the disabled, and women, and rarely the military that consumes half of all domestic spending.

5. This self-aggrandizing ruling class, with help from congressional advocates and sympathizers, decry the national debt, and bulging interest on that debt. Yet, they helped create the debt by lobbying for and achieving reduced taxes on themselves, for outsourcing corporate jobs overseas, and hiding funds in offshore accounts. The Jobs and Growth Tax Relief Reconciliation Act of 2003 during the Bush Administration accelerated the decrease in taxes that benefitted the rich exclusively (Senate and House of Representatives, 2003). The result of these actions is a substantial reduction in both jobs and needed taxes in the U.S. for public services like education.

The present income gap has widened beyond normal expectations and threatened the livelihoods of the majority of workers. As of 2015 , the average family income was $\$ 52,300$, or about where it was in 1996 , and a decline from its high of $\$ 56,000$ in 2007 . There is also a sizeable gap between ethnic and racial incomes, a situation that generates its own imbalanced social dynamic.

A traditional view is that wealth inequality will eventually stabilize over the years and that no state intervention is needed for this to occur. Historical analyses, however, reveal that the concentration of wealth does not automatically equalize. This conclusion is true also in other developed countries. Universally, income from wealth grows faster than wages. The concentration of wealth also implies that the wealthy will have more influence on the political system and manage elected officials to favor its class.

The Survey of Consumer Finances by the Federal Reserve Board in 2014 indicated that a median family headed by a householder under 35 years of age earned $\$ 35,509$. That amount is $6 \%$ less than earned by similar families in the first survey in 1989. Younger families are declining in income further behind older families (Federal Reserve Board, 2014, see also Blow, 2014).

\section{Income Inequality Leads to Education Decline}

The best way to increase average productivity of the labor force and boost the economy is to invest in education. Instead, severe budget cuts have been made throughout all educational levels, reducing the opportunities for the next generation and beyond. This setback comes as increased levels of schooling are required for more sophisticated technical positions. As taxes have been reduced, colleges and universities, whose budgets have been severely curtailed by frugal state governments, have attempted to maintain quality by 
raising tuition rates, thus reducing the numbers of potential students who could attend by pushing them out of the ranks of affordable prospects.

The average spread on a standardized test is about 125 points between the top $10 \%$ of children from rich families and the bottom $10 \%$. This point spread is more than twice the gap between White and African American students. Moreover, the divide is not just between the rich and the poor, but also between the rich and the middle classes. Family income is the chief predictor of schooling success. Income and educational inequality is a global problem. But its damaged image in the U.S. has enlivened educational and political debate about the loss of American educational pre-eminence.

The decline in education is distressing. Millions of Americans are poorly educated working class men and women. About $25 \%$ quit school before high school graduation. Less than high school graduates have only a $20 \%$ chance of earning a minimum wage. The racial and social class divide is apparent to anyone who follows the demographic numbers.

The economic decline impacts education funding at all levels, and is partially responsible for lowered educational standards and negligible test score results. Just as wealth has increased for the wealthy and decreased for the poor, education attainment levels between the wealthy and the poor have also widened. The gap in the U.S. is about $40 \%$ larger than it was in 1980 .

Ideally, there should be a balance between the prudence and frugality of individuals to save for the future. Ideally also, there would be a reasonable set of tax laws that favor the equality of incomes. This implies that the results of individual savings, and the laws limiting excessive wealth, would be adequate for a sufficiently well-paid corps of workers.

According to the Organization for Economic Co-operation and Development (OECD) in 2013, one in six 15-29 year-olds was not in employment, education, or training in the U.S., a higher probability than on average in OECD countries. Conservative governments are thus more likely to have lower tax revenues, have higher welfare unemployment and payments, and have greater social instability because of unemployed and demoralized youth. The other part of the equation is that most youth do not have the skills essential for a global labor market.

It is the loss of jobs that speaks volumes about where America is heading. The loss of manufacturing jobs to foreign countries is over simplified. Technology, especially robotics, not just cheaper labor, has changed how industries compete everywhere. Businesses have adapted to the technology and can be just as efficient with fewer employees. Meanwhile, more and more workers have skills that are outdated for the more sophisticated technological world. About $58 \%$ of the jobs created since 2010 have been in low wage positions, mostly in food services and retail stores. The salaries of these workers are less than $\$ 13.83$ dollars an hour.

Highly educated and highly skilled workers, the winners in the schooling arena, will move to where the higher-paying jobs are, and not just in the U.S.. Most workers cannot or will not relocate, which means lower and middle class Americans will suffer the consequences of globalization and the slow diminishment of wages. But capital moves at electronic speeds and successful businesses adapt to global markets with technological efficiency and with fewer workers (Zakaria, 2012). ${ }^{2}$

Goldin and Katz (2010) analyzed a comparison between high school and college-educated workers between 1890 and 2005 - just as the number of college graduates began to decline — and the rate of growth of

\footnotetext{
${ }^{2}$ Between 1987 and 2007, funding for U.S. corrections and prisons exceeded the expenditures for higher education in 48 states, a statistic that reveals much about funding priorities and social values. More Americans voted for contestants on a TV show than voted for U.S. President (Zakaria, 2012, p. 19).
} 
college degrees increased. They found that wage inequality in the U.S. is a direct result of the failure to invest in higher education. Their research also showed that American working class citizens no longer surpass the educational attainment of their parents. An age gap between generations has emerged as well as an income gap.

The current American fiscal and economic debacle is symptomatic of a larger part of political dysfunction, the division of the country into federalists, who believe that government should work on behalf of the people, and anti-government advocates, or libertarians and their sympathizers, who oppose anything except war or military enhancement. It is a condition Francis Fukuyama (2014) $)^{3}$ describes as "America in Decay, the Sources of Political Dysfunction.”

\section{Conclusion}

Capitalism as a functioning economic system fixes on wealth as the sole objective, on the exercise of the presumed right to pursue personal or corporate self-interest to the detriment of social goals benefitting all. Capitalism has become an end and not the means of achieving social progress. This does not imply that rigid socialism, such as that preached by Karl Marx, or that as existed in the former Union of Soviet Socialist Republics (USSR) when government owned all production, should be the model. Rather, an equitable partnership between government and business for the amelioration of society should be the norm.

Government equalizes business gains by taxing its profits to benefit the commonweal. Government relinquishes its social responsibility when it lowers taxes on wealth and thus exacerbates the inequality between wealth and the less wealthy who become increasingly impoverished.

Wage-earners and day laborers, middle management and small businesses, and householders and housewives, are all trapped in a stagnant economy from which recovery will be slow and uncomfortable. What we do to ourselves is equally uncomfortable as what is done to us economically. Americans are in financial trouble, sometimes spending inordinately and holding disproportionate amounts of personal debt. Government and personal debt have led to a downsizing of educational expenditures, debilitating children and the future job market.

We have to rearrange our scale of individual and group values. National and personal economic interests must become a part of our lifestyle of interests, not the whole of its pursuits, our emphasis on finances subordinated to our social purposes. The discharge of dutiful obligations to society as a whole should never yield to the principle of acquiring wealth at any cost, or to governmental collusion to defer to corporate and business interests to the disservice and handicapping of a balanced social order through the generous and full funding of education programs at all levels.

\section{References}

Barlett, D. L., \& Steele, J. B. (2012). The betrayal of the American dream. New York, N.Y.: Public Affairs.

Blow, C. (2014, March 15). We can't grow the gap away. The New York Times, A18.

Economic Policy Institute. (2014). Retrieved from http://www.epi.org

Federal Reserve Board. (2014, March 15). Survey of consumer finances. Retrieved from http://www.federalreserve.gov/ pubs/bulletin/2014/pdf/scf14.pdf

Fukuyama, F. (2014, September/October). America in decay, the sources of political dysfunction. Foreign Affairs, 93(5), 5-26.

Gilson, D. (2014, September/October). Survival of the richest. Mother Jones, 39(5), 32-35.

Goldin, C. D., \& Katz, L. F. (2010). The race between education and technology: The evolution of U.S. educational wage differentials, 1890-2005. Cambridge, M.A.: The Belnap Press.

\footnotetext{
${ }^{3}$ See similar expressions in Sharpes (2014).
} 
Muller, J. Z. (2013, March/April). Capitalism and inequality. Foreign Affairs, 92(2), 30-51.

Organization for Economic Co-operation and Development (OECD). (2013). Retrieved from http://www.oecd.org

Piketty, T. (2014). Capital in the twenty-first century (A classic research project of the effects of capitalism over the past $300+$ years from an historical perspective by a French economist). Cambridge, M.A.: Belnap Press.

Rhodes, J. H., \& Schaffner, B. F. (2013). Economic inequality and representation in the U.S. house: A new approach using population-level data. Retrieved from http://people.umass.edu/schaffne/Schaffner.Rhodes.MPSA.2013.pdf

Senate and House of Representatives. (2003). Jobs and growth tax relief reconciliation act of 2003 . Retrieved from https://www.govtrack.us/congress/bills/108/hr2/text

Sharpes, D. K. (2014). American economic decline: A consequence of lower educational standards. US-China Education Review $B, 4(8), 560-566$.

Stiglitz, J. (2013). The price of inequality. New York, N.Y.: W.W. Norton.

U.S. Bureau of Labor Statistics. (2014). Retrieved from http://www.bis.gov

U.S. Census Bureau. (2013). Retrieved from http://www.census.gov

Zakaria, F. (2012). The post-American world: Release 2.0. New York, N.Y.: W.W. Norton. 